\section{CarakaTanil \\ Journal of Sustainable Agriculture \\ ISSN 2613-9456 (Print) 2599-2570 (Online)}

\title{
Similarity and Phylogenetic Analysis of Herbicide-Resistant Goosegrass (Eleusine indica) Biotypes
}

\section{Koko Tampubolon ${ }^{1 *}$, Fransisca Natalia Sihombing ${ }^{2}$, Elseria Siburian ${ }^{1}$, Yustina Sri Sulastri ${ }^{1}$, Zavandri Purba ${ }^{3}$, Sony Tri Septian Samosir ${ }^{4}$ and Syahibal Karim ${ }^{4}$}

\author{
${ }^{1}$ Doctoral Program of Agricultural Sciences, Faculty of Agriculture, Universitas Sumatera Utara, \\ Medan, Indonesia; ${ }^{2}$ Master Program of Agribusiness, Faculty of Agriculture, Universitas Sumatera Utara, \\ Medan, Indonesia; ${ }^{3}$ Program Study of Agrotechnology, Faculty of Agriculture, Universitas Sumatera Utara, \\ Medan, Indonesia; ${ }^{4}$ Program Study of Agrotechnology, Faculty of Agro Technology, \\ Universitas Prima Indonesia, Medan, Indonesia \\ ${ }^{*}$ Corresponding author: koko.tampubolon@gmail.com
}

\begin{abstract}
Molecular approach as a herbicide-resistant agent detector is an initial solution before controlling of Eleusine indica weed. This review article is aimed to obtain the basic data of similarity and phylogenetic values among herbicide-resistant $E$. indica biotypes. This research used a descriptive analytical method. The analysis involved 14 nucleotide sequences of herbicide-resistant E.indica biotypes obtained from the National Center for Biotechnology Information. The nucleotide alignment of herbicide-resistant E. indica biotypes was conducted with ClustaLW using the Molecular Evolutionary Genetics Analysis (MEGA) v. 5.05 software based on a method of neighbor-joining tree construct/test. The results showed that two nucleotides of 7,921 herbicide-resistant $E$. indica biotypes were homologous (sequence 1,231 and sequence 1,408). The similarity values among herbicide-resistant $E$. indica biotypes ranged from 0.00 to 1.19 . The information of phylogenetic pattern is needed in the selection of the herbicides mode of action rotation in order to control herbicide-resistant E. indica biotypes.
\end{abstract}

Keywords: goosegrass, herbicides, phylogenetic pattern, resistant

Cite this as: Tampubolon, K., Sihombing, F. N., Siburian, E., Sulastri, Y. S., Purba, Z., Samosir, S. T. S., \& Karim, S. (2019). Similarity and Phylogenetic Analysis of Herbicide-Resistant Goosegrass (Eleusine indica) Biotypes. Caraka Tani: Journal of Sustainable Agriculture, 34(2), 162-169. doi: http://dx.doi.org/10.20961/ carakatani.v34i2.29156

\section{INTRODUCTION}

Integrated weed management (IWM) for sustainable agriculture is seen as an approach in increasing the effectiveness of long-term weed suppression and in reducing environmental contamination (Harker et al., 2012; Shaner, 2014; Liebman et al., 2016) and IWM does not exclude the use of herbicide (Harker et al., 2012; Harker and O'Donovan, 2013). The use of herbicides has increased agricultural profitability, reduced tillage practices that contribute to soil and water

\footnotetext{
* Received for publication April 9, 2019

Accepted after corrections June 28, 2019
}

conservation, increased agricultural labor efficiency and improved farmer's quality of life (Gianessi, 2013; Zimdahl, 2013). The continuous use of similar herbicides in plantations is less effective in suppressing of resistant weeds and can damage soil fertility due to herbicides persistence. Colquhoun (2006) stated that several herbicide families, including imidazolinones, isoxazolidinone, nitriles, glyphosate, dinitroanilines, bipyridyliums, triazines and uracils have moderate to long persistence levels. Selection of the herbicide families that are not-persistent can 
support the management of resistant weeds (MRW) and sustainable agriculture.

The use of herbicides with similar mode of action in controlling weeds are repeated in long period of time resulting in weed resistance (Purba, 2009). Controlling weed populations especially goosegrass [Eleusine indica (L.) Gaertn] on food crops, horticulture and plantations using herbicides with similar mode of action inflicts new problems, like the presence of E. indica biotypes that have herbicide-resistant genes. Baerson et al. (2002) reported that the presence of glyphosate-resistant $E$. indica biotypes was 5-fold higher and amino acids changes occured compared to susceptible populations in the Johor, Malaysia. Chong et al. (2008) stated that glyphosate-resistant $E$. indica biotypes in the Chaah area experienced substitution of Cytosine (C) to Adenine (A) resulting in the change of Threonine $_{106}$ to Proline 106 and substitution of Cytosine (C) with Thymine (T) resulting in the change of Proline ${ }_{106}$ to Serine ${ }_{106}$, in the Bidor area, Malaysia. Takano et al. (2018) stated that the 330bp fragment sequencing of 5-enolpyruvylshikimate-3-phosphate synthase (EPSPS) gene identified a single nucleotide polymorphism that causes the Pro-106-Ser amino acid substitution of glyphosate-resistant biotypes in South America. This mutation caused 3.8-fold increase in glyphosate to inhibit 50\% EPSPS activity. The substitution confirms the occurence of glyphosate resistance. Cha et al. (2014) stated that the target point of Asn-2097-Asp of fluazifop-resistant $E$. indica (biotype P4) in Malaysia experienced a change in nucleotide, in the codon AAT into GAT.

The management of herbicide-resistant $E$. indica biotypes can use the rotation mode of action of herbicides (Monaco et al., 2002). Rotation of herbicide's mode of action will result in genetic amino acids substitution. However, particulary in Indonesia, there has not been any study examining the genetic relationship among herbicide-resistant $E$. indica biotypes using similarity and phylogenetic values. The molecular approach as a detector of herbicide-resistant genes is an initial approach before controlling E. indica in the North Sumatra Province, Indonesia, specifically on the oil palm plantations with glyphosate-resistance of $83.33 \%$ in the South Tapanuli and Batu Bara regency (Tampubolon and Purba, 2018a; Tampubolon et al., 2018a); $89.36 \%$ in the Serdang Bedagai regency (Tampubolon et al., 2018b); 56.62\% in the Deli Serdang regency (Tampubolon et al., 2018c); $42.11 \%$ in the Langkat regency (Tampubolon and Purba, 2018b); 64.69\%; 58.89\%; 72.22\%; 46.43\% and $85.71 \%$, respectively, in the Asahan, Simalungun, Labuhan Batu, North Labuhanbatu and South Labuhanbatu regencies (Tampubolon et al., 2019). The similarity and phylogenetic values of this review article are expected to be the basic strategies for effective and sustainable weed management in plantation companies. Moreover, the strategies can also be integrated with agronomic practices. This review article is aimed to obtain the basic data of similarity and phylogenetic values among herbicide-resistant $E$. indica biotypes.

\section{MATERIALS AND METHOD}

\section{Nucleotide databases of herbicide-resistant $E$. indica biotypes}

This research uses a descriptive analytical method. Database nucleotide from herbisideresistant $E$. indica was used to produce important values of information on biotechnology. This study was carried by recording information of $E$. indica from all databases before 30 March 2019. The analysis involved 14 sequences of nucleotide from herbiside-resistant $E$. indica biotypes from National Center for Biotechnology Information (NCBI) (Table 1).

\section{Similarity and phylogenetic analysis of herbicide-resistant $E$. indica biotypes}

The nucleotide sequences were aligned and similarity scores were obtained using the FASTA format (Pearson and Lipman, 1988). The nucleotide alignment of herbicide-resistant $E$. indica biotypes was conducted with ClustaLW progress (Thompson et al., 1994) using the Molecular Evolutionary Genetics Analysis (MEGA) v. 5.05 software based on a construct/-test neighborjoining tree method. Bootstrap analysis with 1000 replications from neighbor-joining construct/test was used to assess the strength of the nodes in the tree (Tamura et al., 2011). 
Table 1. The accession number of herbicides-resistant $E$. indica biotypes.

\begin{tabular}{|c|c|c|c|c|}
\hline Herbicide site of action* & $\begin{array}{l}\text { Active ingredients of } \\
\text { herbicides* }\end{array}$ & $\begin{array}{l}\text { Sample } \\
\text { name }\end{array}$ & $\begin{array}{l}\text { Accession } \\
\text { number** }\end{array}$ & Region \\
\hline $\begin{array}{l}\text { 5-enolpyruvylshikimate- } \\
\text { 3-phosphate synthase } \\
\text { (EPSPS) }\end{array}$ & Glyphosate, Sulfosate & $\begin{array}{l}\text { EPSPS1 } \\
\text { EPSPS2 } \\
\text { EPSPS3 } \\
\text { EPSPS4 } \\
\text { EPSPS5 } \\
\text { EPSPS6 }\end{array}$ & $\begin{array}{l}\text { AJ417033.1 } \\
\text { KX018289.1 } \\
\text { JN004269.1 } \\
\text { AY395699.1 } \\
\text { AY157643.1 } \\
\text { HQ403647.1 }\end{array}$ & $\begin{array}{l}\text { Malaysia } \\
\text { China } \\
\text { Mississippi } \\
\text { Taiwan } \\
\text { Malaysia } \\
\text { China }\end{array}$ \\
\hline $\begin{array}{l}\text { Glutamine synthetase } \\
\text { (GS) }\end{array}$ & $\begin{array}{l}\text { Glufosinate Ammonium, } \\
\text { Bialaphos, etc. }\end{array}$ & GS1 & KX817292.1 & China \\
\hline $\begin{array}{l}\text { Acetyl-CoA carboxylase } \\
\text { (ACCase) }\end{array}$ & $\begin{array}{l}\text { Sethoxydim, Fluazifop-P- } \\
\text { butyl, Diclofop-methyl, } \\
\text { Propaquizafop, etc. }\end{array}$ & $\begin{array}{l}\text { ACCase1 } \\
\text { ACCase } 2 \\
\text { ACCase3 } \\
\text { ACCase4 }\end{array}$ & $\begin{array}{l}\text { KC778421.1 } \\
\text { KF700369.1 } \\
\text { KF700368.1 } \\
\text { KC778420.1 }\end{array}$ & $\begin{array}{l}\text { United States } \\
\text { United States } \\
\text { United States } \\
\text { United States }\end{array}$ \\
\hline $\begin{array}{l}\text { Acetolactate synthase } \\
\text { (ALS) enzyme }\end{array}$ & $\begin{array}{l}\text { Imazapic, Pyribenzoxim, } \\
\text { Chlorsulfuron, } \\
\text { Cloransulam-methyl, etc. }\end{array}$ & ALS1 & KU720629.1 & China \\
\hline $\begin{array}{l}\text { 4-Hydroxyphenylpyruvate } \\
\text { dioxygenase (HPPD) }\end{array}$ & $\begin{array}{l}\text { Sulcotrione, Isoxaflutole, } \\
\text { Pyrazoxyfen, etc. }\end{array}$ & HPPD1 & AX458025.1 & $\begin{array}{l}\text { United } \\
\text { Kingdom }\end{array}$ \\
\hline $\begin{array}{l}\text { Photosystem I Electron } \\
\text { Diverter (PSI) }\end{array}$ & Paraquat, Diquat & NA & NA & NA \\
\hline Photosystem II (PS II) & $\begin{array}{l}\text { Atrazine, Metribuzin, } \\
\text { Ametryn, Propazine, etc }\end{array}$ & PSII-1 & JX852705.1 & nited States \\
\hline
\end{tabular}

Note: NA (not available from NCBI).

Source: *International Survey of Herbicide-Resistant Weeds

**National Center for Biotechnology Information (NCBI)

\section{RESULTS AND DISCUSSION}

The results of DNA base sequence alignment of herbicide-resistant $E$. indica biotypes from the NCBI database are shown in Figure 1. Based on the gene sequence analysis of 14 herbicideresistant $E$. indica biotypes, there were differences in nucleotide sequences. The nucleotide sequences of herbicide-resistant $E$. indica biotypes resulted in 2 homologous nucleotides (sequence 1,231 and sequence 1,408) from 7,921 nucleotides.

Based on Figure 1, there are substitutions of $E$. indica biotype nucleotides at the same herbicides exposure (ACCase1 to ACCase 2 and ACCase3) in the same country (United States) from $\mathrm{T}$ to $\mathrm{C}$ in the sequence 1,230. According to Huffman et al. (2016) there were three polymorphisms from Tennessee, United States, that changed in the nucleotide sequences from the glyphosate- susceptible $E$. indica into glyphosate-resistant, particularly from $\mathrm{C}$ to $\mathrm{T}$, from $\mathrm{A}$ to $\mathrm{G}$ and from $\mathrm{A}$ to C. According to McCullough et al. (2016) there were nucleotide substitutions in codon Ser-1805 (ACT to TCT) and Asp-2078 (GAT to GGT) of ACCase-resistant $E$. indica biotypes compared to susceptible populations in Georgia. Simarmata and Penner (2008) also reported that nucleotide substitution occured in EPSPS-susceptible Lolium rigidum weed in California from $\mathrm{C}$ to $\mathrm{T}$ (EPSPSresistant biotype) at sequence 301. Zhang et al. (2015) stated that the EPSPS enzyme in glyphosate-resistant $E$. indica biotypes quickly responded at 12 hours after being exposed to glyphosate from South China. The expression of mRNA and protein in the glyphosate-resistant $E$. indica biotype increased, particularly with the increasing of glyphosate dose. Chen et al. (2015) stated that glyphosate-resistant $E$. indica biotype has a small decrease in chlorophyll content at the glyphosate dose of $1,680 \mathrm{~g}$ a.i.ha ${ }^{-1}$. 

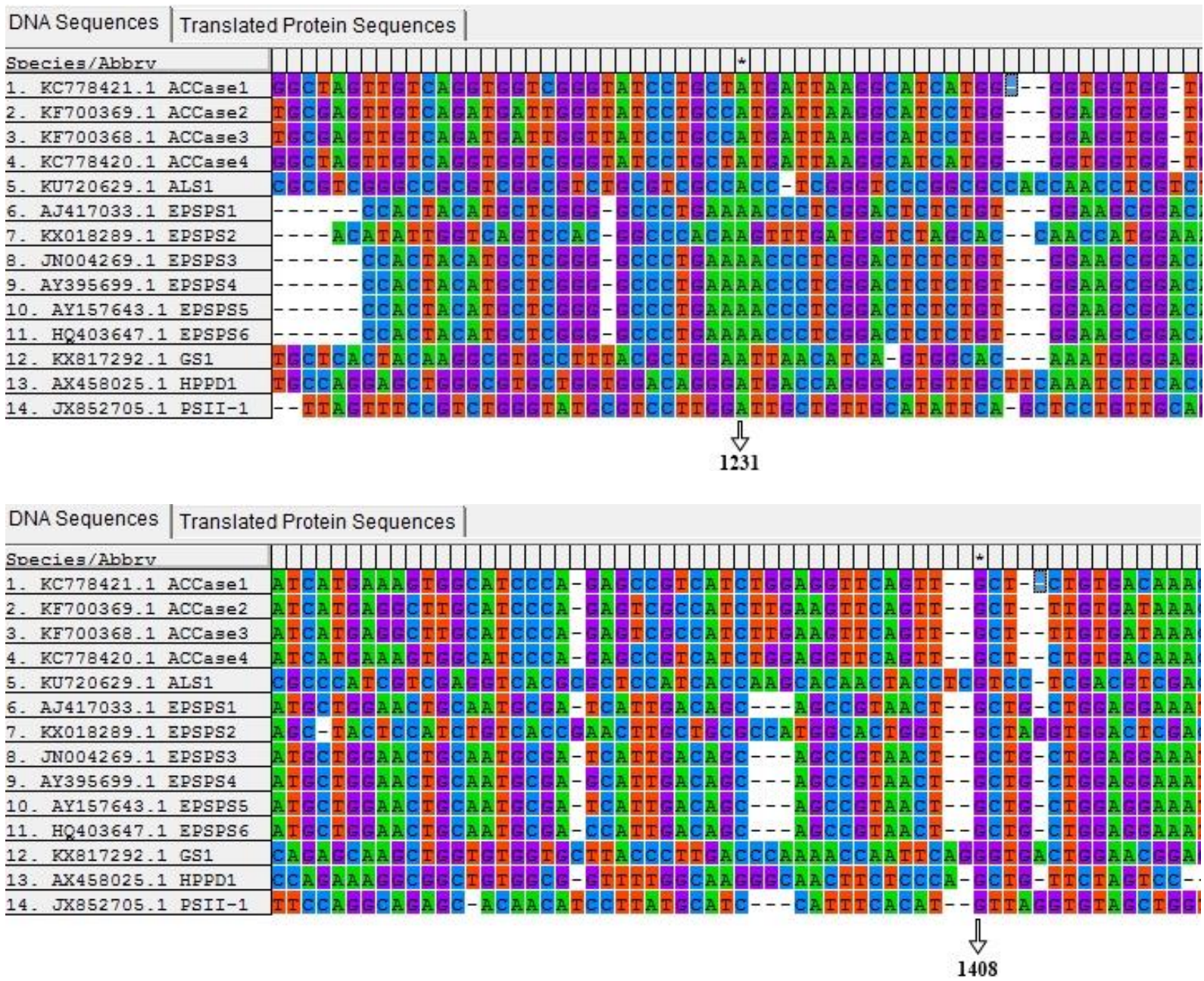

Figure 1. The results of DNA base sequence alignment of herbicide-resistant $E$. indica biotypes from the NCBI database.

The similarity value of herbicide-resistant $E$. indica biotypes ranged from 0.00 to 1.19 (Table 2). The E. indica biotypes showing the smallest genetic distance was found in the KF700369.1 (ACCase2) and KF7003689.1 (ACCase3). This shows that there do not appear any different base pairs in the two accessions. The highest genetic distance was in accession AJ417033.1 (EPSPS1) and KX018289.1 (EPSPS2), meaning that these two accessions had many different base pairs. Chong et al. (2011) also stated that the genetic distance of $14 E$. indica populations (6 glyphosate-resistant and 8 glyphosate-suscep-tible) in the Peninsular Malaysia ranged from $0.000-0.122$. The highest genetic distance value was found in the glyphosate-susceptible $E$. indica from Temerloh and glyphosate-resistant $E$. indica from Bidor area. Saidi et al. (2016) stated that the genetic similarity value of $E$. indica population from 29 locations in Malaysia was $74 \%$ with a genetic distance of 0.37. Galeano et al. (2016) also reported that nine biotypes of glyphosate-resistant Digitaria insularis and six glyphosate-susceptible populations from the State of Sao Paulo, Brazil, had DNA similarity sequences ranging from 74$82 \%$ (high), whereas cDNA sequences (RNA) showed similarity, ranging from $78-94 \%$ (high) with grasses weeds. The highest similarity for cDNA was found in E. indica by $94 \%$. 
Table 2. The genetic similarity distances of herbicide-resistant E.indica biotypes.

\begin{tabular}{|c|c|c|c|c|c|c|c|c|c|c|c|c|c|c|c|}
\hline No & Accession & 1 & 2 & 3 & 4 & 5 & 6 & 7 & 8 & 9 & 10 & 11 & 12 & 13 & 14 \\
\hline 1 & KC778421.1 (ACCase1) & & & & & & & & & & & & & & \\
\hline 2 & KF700369.1 (ACCase2) & 0.16 & & & & & & & & & & & & & \\
\hline 3 & KF700368.1 (ACCase3) & 0.16 & 0.00 & & & & & & & & & & & & \\
\hline 4 & KC778420.1 (ACCase4) & 0.00 & 0.16 & 0.16 & & & & & & & & & & & \\
\hline 5 & KU720629.1 (ALS1) & 1.16 & 1.16 & 1.16 & 1.16 & & & & & & & & & & \\
\hline 6 & AJ417033.1 (EPSPS1) & 0.82 & 0.85 & 0.85 & 0.82 & 1.02 & & & & & & & & & \\
\hline 7 & KX018289.1 (EPSPS2) & 1.06 & 1.08 & 1.08 & 1.06 & 1.06 & 1.19 & & & & & & & & \\
\hline 8 & JN004269.1 (EPSPS3) & 0.88 & 0.90 & 0.90 & 0.88 & 1.11 & 0.17 & 1.15 & & & & & & & \\
\hline 9 & AY395699.1 (EPSPS4) & 0.81 & 0.84 & 0.84 & 0.81 & 1.01 & 0.00 & 1.19 & 0.17 & & & & & & \\
\hline 10 & AY157643.1 (EPSPS5) & 0.87 & 0.90 & 0.90 & 0.87 & 1.11 & 0.16 & 1.14 & 0.00 & 0.17 & & & & & \\
\hline 11 & HQ403647.1 (EPSPS6) & 0.82 & 0.85 & 0.85 & 0.82 & 1.03 & 0.00 & 1.19 & 0.17 & 0.00 & 0.17 & & & & \\
\hline 12 & KX817292.1 (GS1) & 1.16 & 1.12 & 1.12 & 1.16 & 1.13 & 1.04 & 1.11 & 1.07 & 1.05 & 1.07 & 1.05 & & & \\
\hline 13 & AX458025.1 (HPPD1) & 1.00 & 0.97 & 0.97 & 1.00 & 0.74 & 0.90 & 1.02 & 0.93 & 0.90 & 0.93 & 0.91 & 0.95 & & \\
\hline 14 & JX852705.1 (PSII-1) & 1.14 & 1.10 & 1.10 & 1.14 & 1.30 & 1.19 & 1.21 & 1.07 & 1.19 & 1.07 & 1.18 & 1.19 & 1.09 & \\
\hline
\end{tabular}

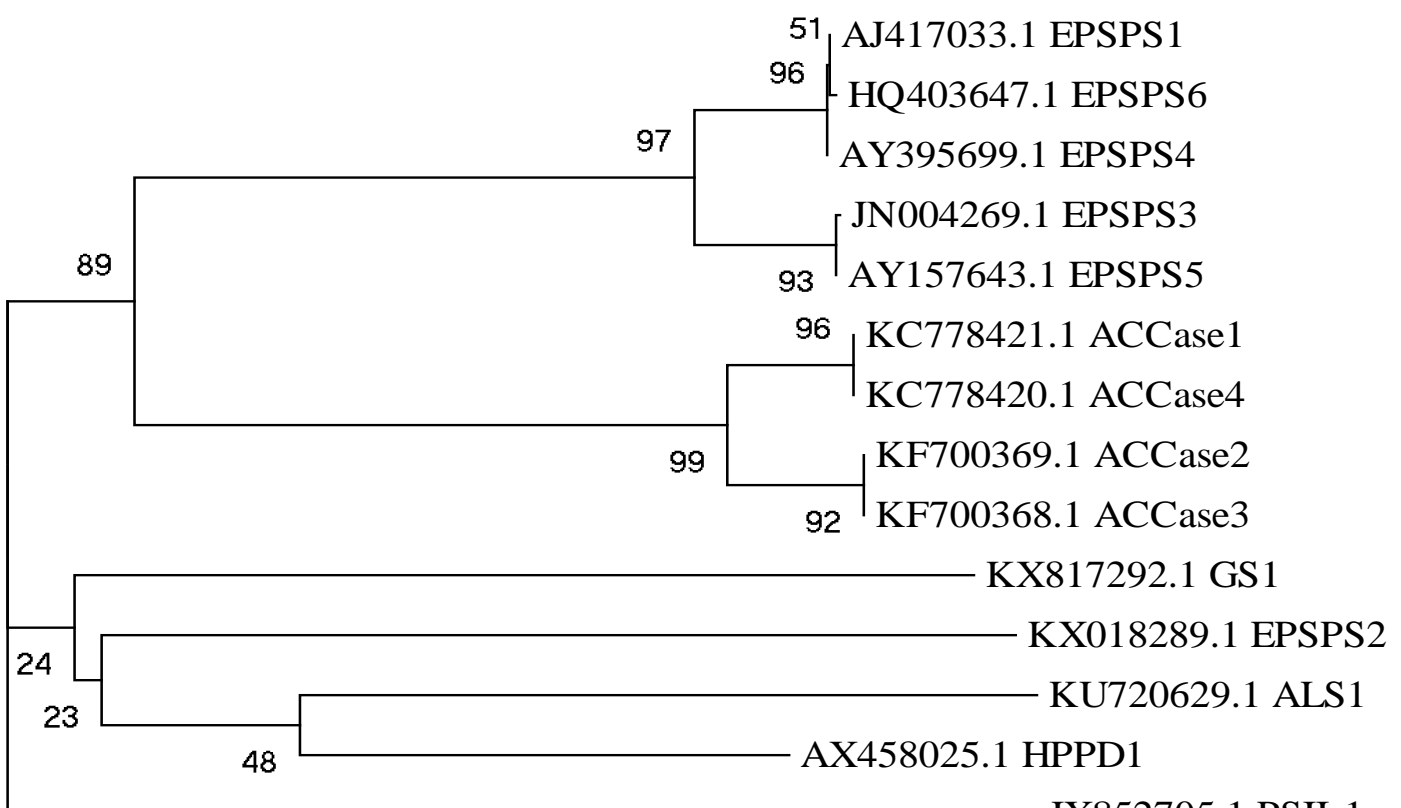

JX852705.1 PSII-1

0.1

Figure 2. The phylogenetic tree of herbicide-resistant E. indica biotypes. The phylogenetic tree was constructed with the neighbor-joining method of the ClustaIW using Mega v. 5.05 Software. Numbers indicate bootstrap value from 1000 replications.

The phylogenetic pattern among herbicideresistant $E$. indica biotypes deriving from the NCBI database (Figure 2). Based on the phylogenetic patterns, three clusters was formed between the biotypes of herbicide-resistant $E$. indica. Cluster 1 consists of the ACCase-resistant E. indica biotypes (KC778421, KF700369, KF700368, KC778420) and EPSPS-resistant $E$. indica biotypes (AJ417033, JN004269, AY395699, AY157643, HQ403647) except KX018289 (EPSPS2) accession. Cluster 2 consists of $E$. indica biotypes with accession of
KX817292 (GS1), KX018289 (EPSPS2), KU720629 (ALS1) and AX458025 (HPPD1). Cluster 3 only consists of JX852705 (PSII-1) accession. There are differences of clusters between accession KX018289 (EPSPS2) and accession HQ403647 (EPSPS6), even though they are originated from the same country (China). This cluster difference is caused by higher genetic diversity in the two accessions (Table 2). There is not any positive relationship among the location of $E$. indica accession in influencing genetic diversity. This is linier with 
Chong et al. (2011) stated that the genetic distance of $14 \mathrm{E}$. indica populations from Peninsular, Malaysia does not correlate with geography situation of the sample, but is attributable to human activities when moving seeds from one to another region. In addition, factors that influence other genetic diversity are genetic drift, inbreeding, and others.

The phylogenetic pattern confirm that the rotational mode of action of the herbicide is able to control of herbicide-resistant $E$. indica biotypes. This phylogenetic information is expected to be able to help farmers and oil palm plantations experiencing problems with herbicide-resistant $E$. indica biotypes in North Sumatra Indonesia, and reporting about the case. Phylogenetic pattern indicates that similar herbicide cannot control E. indica which has been confirmed resistant to similar herbicides. This is linear with Jalaludin et al. (2015) stated that the survival of the glufosinate-resistant $E$. indica biotypes decreased from the dose of 1,278 $\mathrm{g}$ a.i.ha${ }^{1}$ glufosinate ammonium to $292 \mathrm{~g}$ a.i.ha ${ }^{-1}$ paraquat. Simarmata (2009) stated that quizalofop herbicide with the dose of $0.06 \mathrm{~kg}$ a.i.ha ${ }^{-1}$ effectively $(100 \%)$ controlled of glyphosate-resistant rigid ryegrass (Lolium rigidum) compared to glyphosate at the dose of $4.5 \mathrm{~kg}$ a.i.ha ${ }^{-1}$ (only $8 \%$ ) at 3 weeks after treatment. Molin et al. (2013) stated that clethodim, fluazifop-P, paraquat and glufosinate herbicides effectively (95\%, 98\%, $100 \%$ and $80 \%$ ) controlled of glyphosate-resistant E. indica biotype in Washington County, Mississippi. Hambali et al. (2015) confirmed that diuron at the dose of $1,500 \mathrm{~g}$ a.i.ha ${ }^{-1}$ and ametryn at the dose of $1,000 \mathrm{~g}$ a.i.ha ${ }^{-1}$ effectively (100\%) controlled of paraquat-resistant $E$. indica biotype at Afdeling III of Adolina Estate compared to paraquat. In addition, Yulivi et al. (2014) also stated that glyphosate dose of $480 \mathrm{~g}$ a.i.ha ${ }^{-1}$ and glufosinate ammonium dose of $110 \mathrm{~g}$ a.i.ha ${ }^{-1}$ effectively (100\%) controlled of paraquatresistant $E$. indica biotype from Balai Benih Induk (BBI) Tanjung Selamat compared to paraquat.

\section{CONCLUSIONS}

The results of this study show that two nucleotides were homologous (sequence 1,231 and sequence 1,408) of 7,921 nucleotides in the herbicide-resistant $E$. indica biotypes. Similarity values among herbicide-resistant $E$. indica biotypes were ranged from 0.00 to 1.19 .
Phylogenetics pattern confirms that the rotation of mode of action herbicide is able to control of herbicide-resistant $E$. indica biotypes.

\section{REFERENCES}

Baerson, S. R., Rodriguez, D. J., Tran, M., Feng, Y., Biest, N. A., \& Dill, G. M. (2002). Glyphosate-Resistant Goosegrass. Identification of a Mutation in the Target Enzyme 5Enolpyruvylshikimate-3-Phosphate Synthase. Plant Physiology. 129(3), 1265-1275. https://doi.org/10.1104/pp.001560.

Cha, T. S., Najihah, M. G., Sahid, I. B., \& Chuah, T. S. (2014). Molecular Basis for Resistance to ACCase-inhibiting Fluazifop in Eleusine indica from Malaysia. Pesticide Biochemistry and Physiology. 111, 7-13. https://doi.org/ 10.1016/j.pestbp.2014.04.011.

Chen, J. C., Huang, H. J., Wei, S. H., Zhang, C. X., \& Huang, Z. F. (2015). Characterization of Glyphosate-Resistant Goosegrass (Eleusine indica) Populations in China. Journal of Integrative Agriculture. 14(5), 919-925. https: //doi.org/10.1016/S2095-3119(14)60910-2.

Chong, J. L., Wickneswari, R., Ismail, B. S., \& Salmijah, S. (2008). Nucleotide Variability in the 5-Enolpyruvylshikiniate-3-phosphate Synthase Gene from Eleusine indica (L.) Gaertn. Pakistan Journal of Biological Sciences. 11(3), 476-479. https://doi.org/ 10.3923/pjbs.2008.476.479.

Chong, J. L., Wickneswari, R., Ismail, B. S., \& Salmijah, S. (2011). Genetic Diversity of Glyphosate-Resistant and GlyphosateSusceptible Eleusine indica (L.) Gaertn (Poaceae) Populations from Peninsular Malaysia. Malaysian Applied Biology Journal. 40(2), 27-36. Retrieved from http://www. mabjournal.com/index.php?option=com_cont ent $\&$ view $=$ article $\&$ id $=401 \&$ catid $=59$ : currentview $\&$ Itemid $=56$

Colquhoun, J. (2006). Herbicide Persistence and Carryover. Madison, WI: University of Wisconsin Extension, A3819.

Galeano, E., Barroso, A. A. M., Vasconcelos, T. S., López-Rubio, A., Albrecht, A. J. P., Filho, R. V., \& Carrer, H. (2016). EPSPS Variability, Gene Expression, and Enzymatic Activity in Glyphosate-Resistant Biotypes of Digitaria 
insularis. Genetics and Molecular Research. 15(3), 1-15. https://doi.org/10.4238/gmr.1503 8730.

Gianessi, L. P. (2013). The Increasing Importance of Herbicides in Worldwide Crop Production. Pest Management Science. 69(10), 1099-1105. https://doi.org/10.1002/ps.3598.

Hambali, D., Purba, E., \& Kardhinata, E. H. (2015). Dose Response Biotip Rumput Belulang (Eleusine indica (L.) Gaertn.) Resisten-Parakuat terhadap Parakuat, Diuron, dan Ametrin. Jurnal Online Agroekoteknologi. 3(2), 574-580. Retrieved from http:// repository.usu.ac.id/handle/123456789/47004

Harker, K. N., O'donovan, J. T., Blackshaw, R. E., Beckie, H. J., Mallory-Smith, C., \& Maxwell, B. D. (2012). Our View. Weed Science. 60(2), 143-144. https://doi.org/10.1614/WS-D-11-00 177.1 .

Harker, K. N., \& O'donovan, J. T. (2013). Recent Weed Control, Weed Management, and Integrated Weed Management. Weed Technology. 27(1), 1-11. https://doi.org/ 10.1614/WT-D-12-00109.1.

Huffman, J. L., Riggins, C. W., Steckel, L. E., \& Tranel, P. J. (2016). The EPSPS Pro106Ser Substitution Solely Accounts for Glyphosate Resistance in a Goosegrass (Eleusine indica) Population from Tennessee, United States. Journal of Integrative Agriculture. 15(6), 1304-1312. https://doi.org/10.1016/S2095-31 19(15)61220-5.

Jalaludin, A., Yu, Q., \& Powles, S. B. (2015). Multiple Resistance Across Glufosinate, Glyphosate, Paraquat and ACCase-inhibiting Herbicides in an Eleusine indica Population. Weed Research. 55(1), 82-89. https:// doi.org/10.1111/wre.12118.

Liebman, M., Baraibar, B., Buckley, Y., Childs, D., Christensen, S., Cousens, R., Eizenberg, H., Heijting, S., Loddo, D., Merotto, A. and Renton, M. (2016). Ecologically Sustainable Weed Management: How do we get from proof-of-concept to adoption?. Ecological Applications. 26(5), 1352-1369. https://doi.org /10.1002/15-0995.

McCullough, P. E., Yu, J., Raymer, P. L., \& Chen, Z. (2016). First report of ACCase-Resistant Goosegrass (Eleusine indica) in the United
States. Weed Science. 64(3), 399-408. https:// doi.org/10.1614/WS-D-15-00203.1.

Molin, W., Wright, A., \& Nandula, V. (2013). Glyphosate-resistant Goosegrass from Mississippi. Agronomy. 3(2), 474-487. https:// doi.org/10.3390/agronomy3020474.

Monaco J, T., Weller C, S., \& Ashton M, F. (2002). Weed Science: Principles and Practices. New York: John Wiley \& Sons.

Pearson, W. R., \& Lipman, D. J. (1988). Improved Tools for Biological Sequence Comparison. Proceedings of the National Academy of Sciences. 85(8), 2444-2448. https://doi.org/ 10.1073/pnas.85.8.2444.

Purba, E. (2009). Keanekaragaman Herbisida dalam Pengendalian Gulma Mengatasi Populasi Gulma Resisten dan Toleran Herbisida. Pidato Pengukuhan Jabatan Guru Besar Tetap Universitas Sumatera Utara Medan.

Saidi, N., Kadir, J., \& Hong, L. W. (2016). Genetic Diversity and Morphological Variations of Goosegrass [Eleusine indica (L.) Gaertn] Ecotypes in Malaysia. Weed and Turfgrass Science. 5(3), 144-154. https://doi. org/10.5660/WTS.2016.5.3.144.

Shaner, D. L. (2014). Lessons Learned from the History of Herbicide Resistance. Weed Science. 62(2), 427-431. https://doi.org/ 10.1614/WS-D-13-00109.1.

Simarmata, M. (2009). Herbicide Combination for Controlling Glyphosate Resistant Weed. Jurnal Akta Agrosia. 12(1), 83-88. Retrieved from http://repository.unib.ac.id/213/

Simarmata, M., \& Penner, D. (2008). The Basis for Glyphosate Resistance in Rigid Ryegrass (Lolium rigidum) from California. Weed Science. 56(2), 181-188. https://doi.org/ 10.1614/WS-07-057.1.

Takano, H. K., Mendes, R. R., Scoz, L. B., Lopez Ovejero, R. F., Constantin, J., Gaines, T. A., Westra, P., Dayan, F.E \& Oliveira, R. S. (2018). Proline-106 EPSPS Mutation Imparting Glyphosate Resistance in Goosegrass (Eleusine indica) Emerges in South America. Weed Science. 67(1), 48-56. https://doi.org/10.1017/wsc.2018.71.

Tampubolon, K., \& Purba, E. (2018a). Screening 
Single Resistance of Eleusine indica on Oil Palm Plantation in Padang Lawas and Tapanuli Selatan Regency Indonesia. Jurnal Natural. 18(2),101-106. https://doi.org/10. 24815/jn.v18i2.11223.

Tampubolon, K., \& Purba, E. (2018b). Konfirmasi Resistensi Eleusine indica terhadap Glifosat pada Perkebunan Kelapa Sawit di Kabupaten Langkat. Jurnal Pertanian Tropik. 5(2), 276-283. Retrieved from http://jurnal.fp.unila.ac.id/index.php/JA/articl e/download/2798/2337

Tampubolon, K., Purba, E., \& Hanafiah, D. S. (2018a). Resistensi Eleusine indica terhadap Glifosat pada Perkebunan Kelapa Sawit di Kabupaten Batu Bara. Jurnal Agrotek Tropika. 6(3), 133-139. http://dx.doi.org/10.23960/ jat.v6i3.2798.

Tampubolon, K., Purba, E., Basyuni, M., \& Hanafiah, D. S. (2018b). Distribution Mapping of Glyphosate-Resistant Eleusine indica in Serdang Bedagai Regency. Jurnal Natural. 18(3), 127-134. https://doi.org/10.24815/jn. v18i3.11201.

Tampubolon, K., Purba, E., Hanafiah, D. S., \& Basyuni, M. (2018c). Sebaran Populasi dan Klasifikasi Resistensi Eleusine indica terhadap Glifosat pada Perkebunan Kelapa Sawit di Kabupaten Deli Serdang. Caraka Tani: Journal of Sustainable Agriculture. 33(2), 146-152. https://doi.org/10.20961/carakatani. v33i2.24300.

Tampubolon, K., Purba, E., Basyuni, M., \& Hanafiah, D. S. (2019). Glyphosate Resistance of Eleusine indica Populations from North Sumatra, Indonesia. Biodiversitas. 20(7),
1910-1916. https://doi.org/10.13057/biodiv/d2 00717.

Tamura, K., Peterson, D., Peterson, N., Stecher, G., Nei, M., \& Kumar, S. (2011). MEGA5: Molecular Evolutionary Genetics Analysis using Maximum Likelihood, Evolutionary Distance, and Maximum Parsimony Methods. Molecular Biology and Evolution. 28(10), 2731-2739. https://doi.org/10.1093/molbev/m sr121.

Thompson, J. D., Higgins, D. G., \& Gibson, T. J. (1994). CLUSTAL W: Improving the Sensitivity of Progressive Multiple Sequence Alignment through Sequence Weighting, Position-Specific GapPenalties and Weight Matrix Choice. Nucleic Acids Research. 22(22), 4673-4680 https://doi.org/10.1093/ nar/22.22.4673.

Yulivi, T. A., Purba, E., \& Rahmawati, N. (2014). Dose Response Satu Biotip Eleusine indica Resisten-Parakuat terhadap Parakuat, Glifosat, dan Ammonium Glufosinat. Jurnal Online Agroekoteknologi. 2(4), 1339-1346. Retrieved from https://jurnal.usu.ac.id/index.php/agroe koteknologi/article/view/8424

Zhang, C., Feng, L., He, T. T., Yang, C. H., Chen, G. Q., \& Tian, X. S. (2015). Investigating the Mechanisms of Glyphosate Resistance in Goosegrass (Eleusine indica) Population from South China. Journal of Integrative Agriculture. 14(5), 909-918. https://doi.org/ 10.1016/S2095-3119(14)60890-X.

Zimdahl, R. L. (2013). Fundamentals of Weed Science, $4^{\text {th }}$ edition. Amsterdam, The Netherlands: Elsevier/Academic Press. 